\title{
MAJOR CURRENT POLITICAL AND ECONOMIC PROBLEMS FACING EURASIAN COUNTRIES
}

\author{
Mükerrem Hiç \\ Beykent University
}

\section{Introductory}

I would like to begin by thanking the organizers of this international conference not only because they have given me this opportunity to talk to you, but also because they have hit upon a wealth of political and economic problems that Eurasian countries and, in fact, the whole world is passing through today.

Let me stress at the outset that political and economic developments and problems are either directly or indirectly linked to each other. Therefore, I would be dealing here with both. But the problems are so serious, numerous and complicated that, within the time allotted for my talk, I can manage to present to you only a list, without deepening on any major problem.

Let me also note the obvious, that Eurasia itself, as a geographical entity, covers a very large number of countries with different historical, political and economic backgrounds. Hence, we may have to think about different regions or groups of countries. On the European side, even the EU is not homogeneous today. We have the UK, Scandinavian countries, developed continental European countries, Iberian countries, the Balkans and Eastern European. Even in simple developmental terms, we have at least two tiers, a first tier of democratically and economically developed countries, and a second tier with less experience in democracy and less economically developed. In Asia, on the other hand, we have such big countries as Russia, China, Japan and India, as well as such regional groups as South-East Asian countries, Central Asian Turkic-origin countries, the Caucasian, Afghanistan and Pakistan also including Bengladesh, and Middle Eastern, with Iran as a separate politico-economic entity. Similarly, Turkey, at the cross-roads between Europe, Asia and the Middle East, is another but different unique case.

I should also underline here that Turkey has business relations with many of the Eurasian countries. In between the years 1991-2001, Turkey has established Business Councils with the following: Afghanistan, Azarbaijan, Belarussia, Georgia, Kirgizistan, Kazakhistan, Mongolia, Moldova, Uzbekistan, Russia, Tadjikistan, Turkmenistan and Ukraine, plus a "Business Forum" with Pakistan. DEIKK (Turkish International Economic Relations Institution) organizes, at frequent time intervals, a General Meeting of Turkish-Eurasian Business Councils. The last one was held very recently, on November 1, 2010.

\section{Major Political Problems}

Eurasian countries and the world as a whole recently passed through the following major political developments, changes and upheavals:

- Following Perestroika and Glasnost (1985), the demolition of the Berlin Wall (1989), reunification of Germany (1990) and the collapse of Soviet Socialist Union (1991) by which latter event member countries in Eastern Europe and the Balkans gained their independence. They all have adopted democracy and market economy.

- But due to lack of previous experience with democracy and, in some cases, due to lack of sufficient mass education, democracy as well as economic management is far from satisfactory in many of these countries. This evaluation applies to Russia as well, particularly for democracy.

- On the surface, the collapse of the Soviet Union turned the bi-polar world to mono- 
polar. But the USA, as the remaining superpower soon learned that she is not overpowerful; there are strong limits and restraints to her use of military power and diplomatic persuasion. In fact, there is now talk of a multi-polar world in process, with the USA still the most dominant.

- Another concomitant political and economic development was the enlargement and the deepening of the EU. By taking in most of the Balkan and Eastern European countries, the number of EU members now reached 27. A serious effort at economic deepening was first the "Single Market", and more recently the "Euro". The EU is, however, still far from becoming a United States of Europe, politically and militarily.

- Still another Eurasian and world development is the strengthening of the religious factor in the EU and Europe. This is compounded by Islamic terror, Islamic fundamentalism as well as difficulties of adaptation of Moslem immigrants to their host EU countries, and a confusion between real Islam faith and "Islamism" by which I mean fanatical interpretions of Islam and its use (exploitation) for political and commercial purposes.

- Communism as a political and economic regime, on the other hand, seems to be withering away, irrevocably. At present we have only 5 countries that are "people's republic", that is, communist. Of the five, China seems to retain only the dictatorship but implements a mixed economic regime that is open to the world and encourages the private sector and foreign private capital flow with, however, interventionism and excessive protectionism. The rest of the four remaining communist countries, of which three are in South-East Asia, are too small to flare up any major political upheaval, even the erratic North Korea. And all are set to go the way of China in future.

- The recent years also found Eurasia with persistent specific political problems pertaining directly to two or a limited number of countries. These include the Israeli-Palestinian problem in the Middle East; Iraqi occupation by the USA and present withdrawal efforts; Kashmir problem between India and Pakistan; NagornoKarabagh issue between Armenia and Azerbaijan, the Chechen problem in Russia, and the Russian-Georgian-Abkhazian problem, not mentioning the internal problems of China.

\section{Major Economic Problems}

In the global economic area, on the other hand, again we have very important developments and serious problems, many still in transition.

- Since the years ' 70 s most of the Less Developed Countries (LDCs) had turned away from a closed economy model, import-substitution industrialization, interventionism and protectionism towards outward-orientation, market economy and encouragement of private sector and foreign private capital flow. Following this change in mentality, hence economic policies, the world entered since the ' 90 s what is called a globalization process. Globalization involves vast movements of foreign private capital (that is, Direct Private Investments), short and long-term financial funds as well as legal and illegal movement of workers, the first two not only within Developed Countries (DCs) and from DCs to LDCs but also within LDCs and from LDCs to DCs.

- It must be stressed at this point that globalization was aided by the recent technological breakthrough of the computer, the internet and related technologies. Indeed, one may safely foresee that this technological innovation is destined to shape our future in all aspects. The magnitude of its effects will be comparable to 
the industrial revolution of the 18. century, the invention of the steam engine and of electricity.

- As a result of globalization growth rates of all countries rose, those of LDCs more than those of DCs. This signified that globalization is a "win-win" situation and not a "zero-sum-game".

- As a result of differentiated growth, while we had only two groups of countries after the second World War, the DCs and the LDCs, today we have several tiers of countries with respect to per capita income as well as total income level.

- Using the latter criterion we now have the BRICs (Brazil, Russia-India and China) with very high total GNP. That of China, has become second only to the USA, surpassing Japan and others.

Next we have the "emerging markets" that attract large amounts of financial funds and DPIs. Turkey today is rated as an "emerging market".

- But globalization also gave rise to serious, in fact, grave economic problems. Firstly, some countries such as Russia. Turkey, Argentina faced serious economic crises on a single-country basis because of wrong economic policies pursued. But then, in 1997/8 the South-East Asian countries, again because of economic mismanagement, gave rise to a global financial crisis. It was quickly prevented by IMF aid and stand-by agreements and a strong US economy at the time. Followingly, globalization process started to pick up speed again.

- But a much more serious global economic crisis erupted in September 2008. It emanated first in the USA in the financial sector (mortgage or financial crisis) creating a deep recession, then went on to spread to Europe and the DCs and thence to LDCs and the entire world. The ensuing global financial crisis and global recession - which was the worst the world faced, second only to the 1929 Great Depression - was alleviated by means of drastic financial aid to the financial sector plus aid to the automotive sector as well as macro monetary policies, tax policies and extensive government expenditure programs. The latter-mentioned macroeconomic policies were all Keynesian in essence. The entire world and major countries acted in cooperation when taking these measures. And it is noteworthy that the medium of cooperation resorted to was not G8 but G20, that is, 20 countries with the largest GNP. Hence, the group included the BRICs as well as Turkey.

- The negative effects of drastic measures taken to prevent the global economic crisis will continue for some more time in the future. Some individual countries may falter. But a second global dip, initially feared, will likely not come to pass.

-

- It is interesting that the 2008 global crisis will also not likely revert the world away from globalization. Definitely there had been precipitous declines in the level of global flows initially but they are picking up again. Similarly, as the base for globalization, the market economy will also remain in essence despite the contrary remarks made by the French president. The world as a whole will not move towards a French-type dirigiste, that is, excessively interventionist and protectionist economic model.

- On the global scene again, energy supply will still continue to present problems. Petroleum and natural gas is unevenly distributed between countries, while petroleum exploration and production (extraction) is, for a long time, monopolistic. Increased economic growth worldwide raises the world demand for energy but progress in alternative energy sources is unsatisfactory. Energy-saving, on the other hand, is insufficient. Nuclear energy is one way out but it is rightly considered prohibitive because it can easily be turned into a powerful military weapon. 


\section{Major Political and Economic Problems Turkey is Facing}

Major political and economic problems Turkey is facing today is listed below in brief:

- Deficiencies and insufficiencies in the understanding and implementation of democracy.

- The question of insufficient general cultural level.

- Corruption and partisanship as negatively affecting the economy as well as equality of opportunity and social justice.

- The Kurdish and the PKK problem in conjunction with Iraq, the USA and the EU.

- The impasse and dichotomy with regard to Armenia and Azerbaijani relations.

- The question whether the strengthening of religiousness in Turkey poses a threat to laicism or is absorbable and absorbed within the principle of laicism. Is it a strengthening of Islamic faith or Islamism?

- The slackening in Turkey's membership negotiations with the EU; the negative role of the unresolved Cyprus issue, the question whether the EU played fair in the prolongation of this issue; and slowed reform efforts on the part of Turkey.

- Recent turn of Turkey towards Iran, Islamic Middle Eastern countries as well as Russia. The recent political antagonism towards Israel (moving presently to remain only on the surface). The question: is all this an evidence that Turkey is changing her axis? Or is the change dictated merely by economic conditions, the fact that the economy of the EU, Turkey's major economic partner, lost altitude on account of the recent global economic crisis? Or is Turkey now addressing the whole world, and not limiting her relations only with the Western world?

- Imperfections in the practice of "real" market economy.

- Turkey as a route to European energy supply vs. alternative routes that avoid Turkey. It should also be noted here that Turkey is presently host to intensive petroleum explorations in the Black Sea. She will likely host similar explorations in the Mediterranean in the near future. In addition, two nuclear power plants are also planned to be completed by 2020 .

- Too much reliance presently on hot money and flow of funds that do not create production, employment and export opportunities for the Turkish economy. 